\title{
Aspek yuridis program e-karir dalam perspektif hukum ketenagakerjaan
}

\section{Dhaniar Eka Budiastanti ${ }^{1}$, I Gusti Ngurah Adnyana ${ }^{2}$, Adhinda Dewi Agustine ${ }^{3}$.}

${ }^{1}$ Dhaniar Eka Budiastanti; Fakultas Hukum Universitas Merdeka; Jl. Terusan Raya Dieng No. 62-64; Malang; 65146; Jawa Timur; Indonesia.

2 I Gusti Ngurah Adnyana; Fakultas Hukum Universitas Merdeka; Jl. Terusan Raya Dieng No. 62-64; Malang; 65146; Jawa Timur; Indonesia.

${ }^{3}$ Adhinda Dewi Agustine; Fakultas Ilmu Sosial Dan Politik Universitas Merdeka; Jl. Terusan Raya Dieng No. 62-64; Malang; 65146; Jawa Timur; Indonesia.

\section{ART ICLE INFO}

Article history:

Received 2020-05-04

Received in revised form

2020-05-11

Accepted 2020-06-18

Kata kunci:

Elektronik; Karir; Hukum

Ketenagakerjaan.

Keywords:

Electronics; Career; Labor Law.

DOI: https://doi.org/10.26905/

idjch.v11i2. 4397.

How to cite item:

Budiastanti, DE. Adnyana, IGN \&

Agustine, AD. (2020). Aspek

Yuridis Program E-Karir dalam

Perspektif Hukum Ketenagakerjaan.

Jurnal Cakrawala Hukum, 11(2),

147-156. doi:10.26905/

idjch.v11i2. 4397.

Corresponding Author:

* Dhaniar Eka Budiastanti.

E-mail address: debudiastanti@gmail.com

\section{Abstrak}

Kewajiban pengusaha untuk melaporkan lowongan pekerjaan yang ada atau yang akan ada di perusahaannya, telah di atur oleh Peraturan Presiden Nomor 4 Tahun 1980 tentang Wajib Lapor Lowongan Pekerjaan perlu untuk dilakukan penyesuaian dengan kebutuhan masyarakat dan perlu adanya singkronisasi dengan UU Ketenagakerjaan, sehingga dapat memberikan perlindungan hukum bagi pencari kerja atas ketersediaan lowongan pekerjaan di suatu instansi. Berdasarkan ha tersebut maka penulis hendak meneliti tentang aspek yuridis program e-karir dalam perspektif hukum ketenagakerjaan dan perlindungan hukum yang diatur dalam peraturan Ketenagakerjaan terhadap ketersediaan lowongan pekerjaan di suatu instansi. Jenis penelitian ini adalah yuridis normatif dengan pendekatan perundang-undangan dan pendekatan sejarah. Hasil penelitian menunjukkan bahwa Aspek yuridis program e-karir dalam rangka menekan angka pengangguran telah diatur dalam Undang-undang tentang Ketenagakerjaan sebagai salah satu kebijakan strategis berskala nasional. Undang-undang tentang Ketenagakerjaan telah memberikan perlindungan hukum bagi Pencari Kerja atas ketersediaan lowongan pekerjaan di suatu instansi, melalui Pasal 7 dan 8 yang mengatur mengenai perencanaan dan informasi ketenagakerjaan.

\section{Abstract}

The obligation of employers to report existing or future job vacancies in their company has been regulated by Presidential Regulation Number 4 of 1980 concerning Mandatory Reporting of Job Vacancies, it is necessary to make adjustments to the needs of the community and it is necessary to synchronize with the Manpower Law, so that it can provide legal protection for job seekers on the availability of job 


\section{Jurnal Cakrawala Hukum, Volume 11 No. 2 Agustus 2020 \\ ISSN PRINT 2356-4962 ISSN ONLINE 2598-6538}

vacancies in an agency. Based on this, the author wants to examine the juridical aspects of the e-career program in the perspective of labor law and legal protection regulated in the Labor regulations against the availability of job vacancies in an agency. This type of research is normative juridical with a statutory approach and a historical approach. The results showed that the juridical aspects of the e-career program in order to reduce the unemployment rate have been regulated in the Law on Manpower as one of the national scale strategic policies. The Law on Manpower has provided legal protection for Job Seekers for the availability of job vacancies in an agency, through Articles 7 and 8 which regulate employment planning and information.

\section{Pendahuluan}

Tujuan negara membangun adalah untuk kesejahteraan rakyat, maka masalah pengangguran dan inflasi yang tinggi merupakan kondisi yang sangat tidak dikehendaki oleh suatu negara di manapun (Astuti, 2016). Manusia dapat bekerja dengan berusaha secara mandiri dengan menciptakan lapangan kerja sendiri atau bekerja pada orang lain. Pekerjaan yang diusahakan sendiri mengandung arti manusia tersebut bekerja atas usaha modal dan tanggung jawab sendiri. Sedangkan bekerja pada orang lain adalah bekerja dengan bergantung pada orang lain, yang memberi Perintah dan mengutusnya, karena ia harus tunduk dan patuh pada orang lain yang memberikan pekerjaan tersebut (Asikin, Zainal, 2016). Manusia yang hendak bekerja pada orang lain ini harus melihat ketersediaan lapangan pekerjaan yang ada. Fenomena yang terjadi saat ini adalah banyaknya pencari kerja dengan ketersediaan lapangan pekerjaan tidak sepadan, sehingga menyebabkan angka pengangguran (Sensus Penduduk, 2001) semakin tinggi dari tahun ke tahun.

Tingginya angka pengangguran di Indonesia dapat dilihat dari data yang telah disajikan oleh Badan Pusat Statistik (selanjutnya disebut dengan BPS) mengenai Tingkat Pengangguran Terbuka (untuk selanjutnya disebut dengan TPT). Menurut data yang telah disajikan oleh BPS per Agustus tahun 2019, data tersebut menunjukkan bahwa 7,05 juta jiwa penduduk di Indonesia tidak memiliki pekerjaan. Data yang disajikan oleh BPS tersebut menunjukkan bahwa jumlah pengangguran tersebut meningkat 3,3 persen dibandingkan dengan bulan Februari yang berjumlah sebesar 6,82 juta jiwa penduduk yang tidak memiliki pekerjaan. Kepala BPS menyatakan bahwa mayoritas penduduk yang mengalami pengangguran adalah lulusan sekolah menengah kejuruan (SMK). Selain SMK, peringkat kedua yang mengalami pengangguran adalah lulusan Sekolah Menengah Atas (SMA) dengan persentase 7,92 persen. Pada peringkat ketiga, penduduk yang mengalami masalah pengangguran adalah lulusan diploma I/II/III sebesar 5,99, selanjutnya adalah lulusan universitas sebesar 5,67 persen, Sekolah Menengah Atas (SMP) Sebesar 4,75 persen, dan Sekolah Dasar (SD) sebesar 2,41 persen (BPS Indonesia, 2019).

Berdasarkan data tersebut diatas, maka dapat terlihat bahwa Tingkat Pengangguran Terbuka (TPT) terlihat mengalami kenaikan dari 5,01 persen pada Februari 2019 menjadi 5,28 persen pada bulan Agustus 2019. Namun demikian, angka tersebut terlihat lebih baik jika dibanding dengan bulan Agustus tahun 2018, yaitu sebesar 5,34 persen. TPT merupakan suatu indikasi mengenai penduduk usia kerja yang tergolong dalam kelompok pengangguran (BPS Indonesia, 2019).

Merujuk pada konstitusi Negara, yaitu Undang-Undang Dasar Negara Republik Indonesia Tahun 1945 (UUD NRI 1945), Pasal 27 ayat (2) UUD NRI 1945, menetapkan bahwa "setiap warga 


\section{Aspek yuridis program e-karir dalam perspektif hukum ketenagakerjaan}

Dhaniar Eka Budiastanti, I Gusti Ngurah Adnyana, Adhinda Dewi Agustine

negara berhak atas pekerjaan dan penghidupan yang layak bagi kemanusiaan". Berdasarkan isi pasal 27 ayat (2) UUD NRI 1945 tersebut, maka dapat disimpulkan bahwa dalam hal ini negara menjamin setiap warga negara Indonesia untuk dapat memperoleh pekerjaan yang layak guna mencukupi kehidupan sehari-hari dengan tanpa syarat (Pulungan, Muhamad Sholeh, 2018). Dengan demikian dalam mengatasi persoalan pengangguran, pemerintah harus memberikan solusi dan upaya dalam mengatasi masalah pengangguran dengan kebijakan dan regulasi yang dapat diterapkan dengan baik dan efektif.

Ketentuan Pasal 27 ayat (2) UUD NRI 1945 tersebut diatas, dijabarkan lebih lanjut dalam Pasal 4 Undang-Undang Republik Indonesia Nomor 13 Tahun 2003 tentang Ketenagakerjaan (selanjutnya disebut dengan UU Ketenagakerjaan). Pasal 4 UU Ketenagakerjaan menjelaskan bahwa pembangunan ketenagakerjaan bertujuan untuk: “(1). Memberdayakan dan mendayagunakan tenaga kerja secara optimal dan manusiawi; (2). Mewujudkan pemerataan kesempatan kerja dan penyediaan tenaga kerja yang sesuai dengan kebutuhan pembangunan nasional dan daerah; (3). Memberkan perlindungan kepada tenaga kerja dalam mewujudkan kesejahteraan; dan (4). Meningkatkan kesejahteraan tenaga kerja dan keluarganya". Untuk dapat melaksanakan tujuan di bidang ketenagakerjaan, maka berdasarkan Pasal 7 UU Ketenagakerjaan, ditetapkan perencanaan tenaga kerja dan informasi ketenagakerjaan, yang meliputi: “(1). Penetapan kebijakan pemerintah dan penyusunan perencanaan tenaga kerja; (2). Perencanaan tenaga kerja makro dan mikro; (3). Penyusunan kebijakan, strategi, dan pelaksanaan program pembangunan ketenagakerjaanyang berkesinambungan, pemerintah harus berpedoman pada kebijakan yang telah dibuatnya". Lebih lanjut, Pasal 8 ayat (1) UU Ketenagakerjaan menentukan bahwa perencanaan tenaga kerja disusun atas dasar informasi ketenagakerjaan, yang diantaranya meliputi informasi kesempatan kerja dan Pasal 8 ayat (2) menyebutkan bahwa: “ informasi ketenagakerjaan tersebut diperoleh dari semua pihak baik pemerintah maupun swasta". Tata cara yang terkait dengan cata untuk memperoleh informasi ketenagakerjaan tersebut diatur dengan Peraturan Pemeritah, demikian diatur oleh Pasal 8 ayat (3) UU Ketenagakerjaan.

Berdasarkan peraturan tersebut diatas, maka sudah seharusnya baik Pemerintah Pusat maupun Pemerintah Daerah untuk melakukan usaha-usaha guna memberantas atau minimal menurunkan angka pengangguran yang ada di Indonesia. Tenaga kerja secara sosial ekonomis mempunyai kedudukan yang lemah dan pengetahuan yang rendah, sehingga seringkali mendapat perlakuan yang tidak adil. Upaya untuk memperjuangkan hak-haknya tidak mempunyai kemampuan yang memadai sehingga para tenaga kerja sering melakukan tindakan yang bernuansa politis. Hal itu dilakukan agar supaya mendapatkan dukungan publik untuk memperjuangkan hak-hak normatifnya. Termsuk memperjuangkan perbaikan kesejahteraan hidup bersama keluarganya. (Adnyana, 2017)

Pemerintah mengatur penyediaan tenaga kerja dalam kuantitas dan kualitas yang memadai serta untuk memberikan pelayanan sebaik-baiknya kepada para pencari kerja termasuk penempatan tenaga kerja yang tepat guna, maka diperlukan data mengenai keadaan lowongan pekerjaan, sehingga Pemerintah dapat mengatur penyebaran tenaga kerja secara efektif dan efisien (Kepres No. 4 Tahun 1980).

Salah satu upaya yang dapat ditempuh oleh pemerintah untuk menurunkan angka pengangguran tersebut adalah dengan memanfaatkan tekhnologi informasi. Melalui internet pemerintah dapat berinovasi demi memberikan informasi lowongan pekerjaan dan pelatihan kerja untuk masyarakat sekitar (e-karir). E-Karir dapat di terapkan oleh pemerintah untuk memperoleh data mengenai keadaan lowongan pekerjaan. Untuk terlaksananya program ini, maka sekiranya perlu ada- 


\section{Jurnal Cakrawala Hukum, Volume 11 No. 2 Agustus 2020}

ISSN PRINT 2356-4962 ISSN ONLINE 2598-6538

nya ketentuan yang mewajibkan pengusaha untuk melaporkan lowongan pekerjaan yang ada atau yang akan ada di perusahaannya, sehingga dapat disalurkan pemerintah kepada Masyarakat.

Terkait dengan kewajiban pengusaha untuk melaporkan lowongan pekerjaan yang ada atau yang akan ada di perusahaannya, di Indonesia terdapat suatu regulasi yang khusus mengatur mengenai wajib lapor lowongan pekerjaan yang ada dan/ atau akan ada di perusahaannya, yaitu Peraturan Presiden Nomor 4 Tahun 1980 tentang Wajib Lapor Lowongan Pekerjaan (selanjutnya disebut dengan PP Nomor 4 Tahun 1980). Akan Tetapi PP Nomor 4 Tahun 1980 ini lama tidak mengalami perubahan sehingga sangat perlu untuk dilakukan penyesuaian dengan kebutuhan masyarakat dan perlu adanya singkronisasi dengan UU Ketenagakerjaan, sehingga dapat memberikan perlindungan hukum bagi pencari kerja atas ketersediaan lowongan pekerjaan di suatu instansi.

\section{Metode}

Jenis penelitian yang digunakan dalam penelitian ini adalah Yuridis Normatif, dengan pertimbangan karena sasaran dari penelitian ini adalah menganalisis aspek hukum program e-karir dalam perspektif hukum ketenagakerjaan, serta beberapa Peraturan regulasi yang terkait dengan pengadaan ketenagakerjaan dalam perspektif hukum ketenagakerjaan. Pendekatan penelitian yang digunakan adalah pendekatan perundang-undangan (Statue Approach) dan pendekatan sejarah (Historical Approach). Pendekatan ini akan membantu menemukan dan menjelaskan keterkaitan hukum dan masyarakat. (Hakim, 2016)

\section{Pembahasan}

A. Aspek yuridis program elektronik karir (ekarir) dalam perspektif hukum ketenagakerjaan

Pada hakikatnya, penegasan tentang hak bekerja dan pekerjaan di satu sisi merupakan upaya yang dilakukan pemerintah untuk mereduksi permasalahan yang terjadi pada bidang ketenagakerjaan pada umumnya (Kahfi, 2016). Informasi yang terkait dengan ketenagakerjaan akan dikumpulkan serta diolah sesuai dengan maksud dan tujuan disusunnya perencanaan tenaga kerja nasional, perencanaan tenaga kerja daerah, propinsi atau kabupaten/kota. Berdasarkan hal tersebut, maka partisipasi perusahaan swasta diharapkan dapat memberikan lowongan pekerjaan yang terseia di perusahaannya. Informasi yang terkait dengan ketenagakerjaan ini telah diatur dalam pasal $8 \mathrm{UU}$ Ketenagakerjaan, yang diantaranya adalah meberikan informasi pekerjaan atau lowongan pekerjaan yang tersedia. Menurut Soerjono Soekanto, tolak ukur penegakan hukum dipengaruhi oleh lima hal antara lain faktor hukum, faktor penegak hukum, faktor sarana dan fasilitas pendukung, faktor masyarakat dan faktor kebudayaan (Lestariyono, 2019). Beberapa factor tersebut dalam hukum ketenagakerjaan salah satu faktornya adalah dengan memberikan fasilitas program EKarir.

Dengan diwajibkannya perusahaan swasta atau pemerintah untuk memberikan Informasi kepada para pencari kerja, maka salah satu terobosan yang diberikan oleh Dinas Ketenagakerjaan adalah membuat layanan Elektronik Karir. Elektronik Karir atau E-Karir merupakan suatu progam yang di desain guna memberikan informasi lapangan pekerjaan kepada pencari kerja. Pembentukan program elektronik karir memiliki tujuan untuk dapat menyelesaikan permasalahan sosial yang ada di masyarakat, dimana salah satu permasalahan tersebut salah satunya adalah pengangguran. Tujuan lain di bentuknya program E-Karir ini adalah bahwa untuk dapat menarik perhatian perusahaan-perusahaan swasta untuk berpartisipasi dalam pelaksanaan program elektronik karir.

Program E-Karir merupakan bagian dari hukum ketenagakerjaan, yang artinya apabila hendak membahas mengenai hukum ketenagakerjaan, 


\section{Aspek yuridis program e-karir dalam perspektif hukum ketenagakerjaan}

Dhaniar Eka Budiastanti, I Gusti Ngurah Adnyana, Adhinda Dewi Agustine

maka harus diketahui pula hal-hal yang terkait dengan sumber hukum Indonesia di bidang Ketenagakerjaan. Sumber hukum adalah tempat dimana kita dapat menemukan aturan hukum. Sumber hukum dapat dibedakan menjadi dua, yaitu sumber hukum formil dan sumber hukum materiil. Sumber hukum ketenagakerjaan merupakan sumber hukum Indonesia di bidang ketenagakerjaan, dimana untuk mengetahui perkembangan mengenai hukum ketenagakerjaan di Indonesia, hal yang harus diketahui adalah sejarah dan politik hukum ketenagakerjaan, yang akan di jelelaskan sebagai berikut:

1. Sejarah dan politik hukum ketenagakerjaan Sejarah hukum ketenagakerjaan Indonesia selalu berkaitan dengan politik hukum yang diberlakukan oleh penguasa yang memerintah pada saat itu. Sejarah hukum ketenagakerjaan dapat dibagi menjadi 3 (tiga) periode, yaitu: (Wijayanti, Asri, 2018) "Masa sebelum proklamasi 17 Agustus 1945; Masa Pasca Proklamasi 17 Agustus 1945; dan Masa Reformasi."

a. Masa sebelum proklamasi 17 agustus 1945 Pada era sebelum proklamasi kemerdekaan, yakni pada masa sebelum tanggal 17 Agustus 1945, sejarah hukum ketenagakerjaan dapat dibagi dalam 3 (tiga) bagian, yakni ketika pada masa perbudakan, penjajahan Hindia Belanda, serta kependudukan jepang.

\section{1) Masa Perbudakan}

Pada masa perbudakan ini, di Indonesia telah mengenal hukum adat. Dalam masa perbudakan ini terdapat suatu istilah bahwa budak adalah milik majikan. Istilah budak adalah milik majikan ini memiliki arti bahwa hal-hal yang terkait dengan perekonomian dan nyawa seseorang juga menjadi milik atau kekuasaan dari majikan. Terkait dengan hal tersebut, maka kesejahteraan rakyat juga sangatlah bergantung pada kewiba- waan dari penguasa (raja) yang memerintah pasa suatu periode. Contoh dari hidup dan mati rakyat adalah milik majikan adalah ketuka pada tahun 1877, ketika Raja Sumba mati, maka dampaknya ada 100 orang yang mati terbunuh, dengan alasan bahwa agar raja tersebut dalam alam bana memiliki pelayan yang akan melayaninya.

Selain istilah budak adalah milik majikan, dalam periode perbudakan ini juga dikenal lembaga perhambaan dan peluluran. Lembaga peluluran ini dapat terjadi apabila ada hubungan hukum berupa perjanjian hutang piutang atau terdapat hubungan hukum pinjam meminjam. Ketika ada hutang piutang, apabila pihak debitur atau si peminjam tidak dapat membayarkan hutangnya kepada kreditur atau orang yang meminjamkan, maka pihak debitur dengan ini akan menyerahkan dirinya kepada pihak kreditur sebagai hamba sampai dengan pihak debitur bisa membayarkan hutangnya. Dengan di serahkannya diiri debitur kepada kreditur inilah, maka debitur akan menjadi budak dari kreditur sebagai wujud jaminan dan hal ini hanya diangap sebagai wujud pembayaran bunga.

Terdapatnya lembaga peruluran ini terjadi setelah Jan Pieterszoon Coen pada tahun 1621 telah berhasil untuk menguasai "pulau Belanda". Orang yang terdapat di dalam pulau itu akan memiliki dua pilihan, yaitu dibunuh atau dibawa keluar negeri sebagai budak. Setelah itu, maka tanah kosong akan di bagikan kepada bekas kompeni atau orang lain. Kepemilikan dari tanah tersebut hanyalah sebatas 
ketika orang tersebut melakukan wajib tanam dan ketika orang tersebut tinggal diatas tanah tersebut. Hasil dari wajib tanam tersebut akan dijual kepada kompeni dengan harga yang begitu tingggi sesuai dengan hara yang telah di tentukan oleh kompeni. Wajib tanam ini yang kemudian menjadi bagian dari tanam paksa dan terus berlangsung sampai dengan tahun 1963.

2) Masa penjajahan Hindia Belanda Pada masa penjajahan Hindia Belanda, tidak seluruh wilayah yang ada di Indonesia diakuasai oleh belanda. Hal ini disebabkan karena masih terdapatnya wilayah yang menjadi daerah kekuasaan Raja yang memiliki kedaulatan yang utuh akan dawrah atau wilayah yang sedang dikuasainya. Masa penjajahan Belanda ini, meliputi "masa kependudukan Inggris, masa kerja rodi dan masa poenale sactie". Pada Tahun 1811 sampai dengan tahun 1816, saat pendudukan Inggris yang dipimpin oleh Thomas Stamford Rafless, belanda mendirikan "The Java Bevennolent Institution" dengan tujuan untuk menghapus perbudakan yang ada di Indonesia. Akan tetapi rencana ini belum terwujud dan terlaksana dikarenakan Inggris telah ditarik mundur.

Rodi dapat dibagi menjadi 3 (tiga) Bagian, yaitu "rodi gubernemen (untuk kepentingan gubernemen dan pegawai), rodi perorangan (untuk kepentingan kepala atau pembesar Indonesia), dan rodi desa (untuk kepentingan desa)".

Rodi yang digunakan untuk para pembesar dan gubernemen "(disebut dengan panen)" ini sangat membuat be- ban rakyat menjadi sangat berat. Hal ini dikarenakan keputusan dan ketetapannya diserahkan kepada Belanda. "Convention nomor 29 Concering forced or compulsory labour (kerja paksa atau kerta wajib yang di ratifikasi oleh belanda pada tahun 1993), tidak memandang kerja wajib untuk keperluan tantara dan orang lain dalam pekerjaan ketentaraan serta rodi untuk kepentingan desa sebagai yang terlarang".

"Selanjutnya menurut Jan Breman ponale sactie diterapkan dalam kaitannya dengan penerapan Koeli ordonantie serta Agrarish wet dalam melakukan hubungan kerja antara buruh yang bekerja di tanah pertanian dan perkebunan. Politik hukum ketenagakerjaan berkaitan erat dengan politik hukum agrarian, mengingat banyak tenaga kerja yang bekerja di tanah pertanian."

Poenali sanctie memiliki tujuan, yakni guna mengikat dan mempertahankan buruh agar tidak dapat melarikan diri setelah mereka membuat kontrak kerja. Kontrak kerja saat terkesan semu karena dalam perjanjian tersebut tidak di berikan tanda tangan, sehingga buruh tidak dapat mengakhiri hubungan kerja.

3) Masa pendudukan Jepang

Periode kependudukan Jepang ini terjadi mulai tanggal 12 Maret 1942, dimana pemerintah militer Jepang membagi tiga daerah kependudukan, yaitu "Jawa, Madura, dan Sumatra yang dikontrol dari Singapura dan Indonesia Timur". Pada masa ini Jepang fokus untuk mempertahankan diri dari serangan sekutu, sera menguras habis kekayaan Indonesia. Hal ini 


\section{Aspek yuridis program e-karir dalam perspektif hukum ketenagakerjaan}

Dhaniar Eka Budiastanti, I Gusti Ngurah Adnyana, Adhinda Dewi Agustine

dilakukan semata-mata untuk kepentingan Perang Asia Timur Raya. Pada Masa kepenndudukan jepang ini juga di terapkan sistem romusya dan kinrohosyi. Romusa merupakan tenaga sukarela. Romusa local adalah mereka yang dipekerjakan dalam tempo atau jangka waktu yang pendek. Romusha lokal ini juga disebut dengan kinrohosyi.

2. Masa pasca proklamasi 17 agusus 1945 "Sejarah perkembangan hukum ketenagakerjaan Indonesia pada masa pasca Proklamasi 17 Agustus 1945, pada prinsipnya dapat dibagi ke dalam 2 periode, yaitu masa pemerintahan Soeharto dan masa kepemimpinan Soekarno". Pada masa pemerintahan Soekarno kebijakan mengenai ketenagakerjaan tidak terlalu banyak. Hal ini terjadi karena masa itu merupakan masa untuk mempertahankan wilayah Negara Kesatuan Republik Indonesia (NKRI) dari jajahan Hindia Belanda. Di bidang hukum ketenagakerjaan, pada saat ini pemerintah masih banyak menterjemahkan hukum Hindia Belanda.

Selanjutnya, pada masa kepemimpinan Soeharto, kedudukan buruh semakin melemah. Melemahnya kedudukan buruh tersebut dikarenakan hubungan Industrial Pancasila. Hak buruh semakin ditekan.Hal ini ditandai dengan hanya dapat dibentuknya satu serikat pekerja, yaitu "Serikat Pekerja Seluruh Indonesia (SPSI)".

3. Masa reformasi

Pasca reformasi, dibagi dalam empat masa pemerintahan, yaitu masa pemerintahan Baharudin Jusuf Habibie, masa pemerintahan Abdurrahman Wahid, masa pemerintahan Megawati, dan mada pemerintahan Susilo Bambang Yudhoyono. Masa kepemimpinan BJ Habibie, kondisi perekonomian di Indonesia semakin membaik. Hal ini di tandai dengan meningkatnya kepercayaan luar negeri kepada negara Indonesia. Mereka beranggapan bahwa Indonesia dapat mengatasi permasalahannya sendiri tanpa mengabaikan Hak Asasi Manusia (HAM). Selain itu, Indonesia juga memiliki peranan yang begitu besar dalam melaksanakan demokrasi Indonesia. Demokrasi Indonesia ini kemudian di lanjutkan ketika pemerintahan sudah beralih ke Abdurrahman Wahid. Hal ini di tandai dengan terbentuknya Undang-undang Nomor 21 Tahun 2000 Tentang Serikat Pekerja atau Serikat Buruh. Masa pemerintahan Megawati, diperintahkan supaya ada suatu keputusan yang berasal dari Majelis Permusyawaratan Rakyat (MPR) mengenai penolakan laporan pertanggungjawaban dari Abdurrahmanwahid. Perkembangan dalam dunia ketenagakerjaan hampir tidak ada kemajuan. Justru yang terlihat adalah semakin banyaknya kasus ketenagakerjaan. Pada saat pemerintahan di lanjutkan ke periode Susilo Bambang Yudhoyono, perkembangan di ketenagakerjaan mulain nampak dengan munculnya berbagai upaya peningkatan layanan dan kinerja baik pekerja maupun pegawainya.

Berdasarkan pemaparan terkait dengan sejarah ketenagakerjaan di Indonesia tersebut diatas, maka dapat disimpulkan bahwa permasalahan ketenagakerjaan sudah ada sejak sebelum proklamasi kemerdekaan tanggal 17 Agustus 1945. Politik ketenagakerjaan selalu mengalami perubahan seiring dengan pergantian kekuasaan. Permasalahan terkait dnegan ketenagakerjaan, yang terjadi saat ini bukan hanya pada tenaga kerjanya saja, akan tetapi dalam setiap lingkup dan pengaturan operasional hukum ketenaga kerjaan, yang salah satunya adalah masa sebelum bekerja (pre-employment). Pada masa pre employment ini, permasalahan yang terjadi adalah masalah pengadaan tenaga kerja yang meliputi pengaturan lowongan kerja, pengerahan, dan penempatan. 
Melihat pentingnya hal-hal tersebut, maka hal yang perlu dicermati dan ditetapkan regulasi adalah hal yang terkait dengan pengaturan lowongan kerja. Hal ini perlu diatur untuk mempermudah akses para pencari kerja untuk mendapatkan informasi pekerjaan, sehingga dapat menekan angka pengangguran yang adal di Indonesia.

Perkait dengan peraturan yang mengatur mengenai kewajiban perusahaan atau pemerintah untuk menyalurkan informasi terkait dengan lowongan pekerjaan, Indonesia telah memiliki regulasi yang mengatur mengenai hal tersebut diantaranya melalui Keputusan Presiden Nomor 4 Tahun 1980 tentang Wajb Lapor Lowongan Pekerjaan (selanjutnya di sebut PP No 4 Tahun 1980).

Konsideran PP No 4 Tahun 1980 disebutkan bahwa "bahwa dalam rangka Pemerintah mengatur penyediaan tenaga kerja dalam kuantitas dan kualitas yang memadai serta untuk memberikan pelayanan sebaik-baiknya kepada para pencari kerja termasuk penempatan tenaga kerja yang tepat guna, maka diperlukan data mengenai keadaan lowongan pekerjaan, sehingga Pemerintah dapat mengatur penyebaran tenaga kerja secara efektif dan efisien". Pasal 2 PP No 4 Tahun 1980 menyebutkan bahwa: "Setiap Pengusaha atau pengurus wajib segera melaporkan secara tertulis setiap ada atau akan ada lowongan pekerjaan kepada Menteri atau Pejabat yang ditunjuknya. Laporan sebagaimana dimaksud dalam ayat (1) memuat: Jumlah tenaga kerja yang dibutuhkan; Jenis pekerjaan dan syarat-syarat jabatan yang digolongkan dalam jenis kelamin, usia, pendidikan, ketrampilan/keahlian, pengalaman dan syarat-syarat lain yang dipandang perlu."

Berdasarkan hal tersebut maka dapat disimpulkan bahwa salah satu cara pemerintah untuk mengatasi permasalah pengangguran yang ada di Indonesia adalah dengan menggunakan E-Karir. Program E-Karir dalam menekan angka pengangguran di Indonesia saat ini secara umum juga di atur dalam UU Ketenagakerjaan, melalui ketentuan Pasal 7 dan 8 UU Ketenagakerjaan. Hal ini sesuai dengan Pasal 27 ayat (2) UUD NRI 1945, menetapkan bahwa "setiap warga negara berhak atas pekerjaan dan penghidupan yang layak bagi kemanusiaan".

\section{B. Perlindungan hukum yang diberikan undang-undang nomor 13 tahun 2003 tentang ketenagakerjaan terhadap pencari kerja atas ketersediaan lowongan pekerjaan di suatu instansi}

Perlindungan hukum merupakan gambaran dari bekerjanya fungsi hukum untuk mewujudkan tujuan-tujuan hukum, yaitu keadilan, kemanfaatan, dan kepastian hukum. Perlindungan hukum adalah suatu perlindungan yang diberikan kepada subjek hukum sesuai dengan aturan hukum, baik yamg bersifat prefentif (pencegahan) maupun represif (pemaksaan), baik yang secara tertulis maupun tidak tertulis dalam rangka menegakkan peraturan hukum.

Menurut Hadjon, perlindungan hukum bagi masyarakat meliputi dua hal, yaitu: Perlindungan hukum preventif, yaitu bentuk perlindungan hukum dimana rakyat diberi kesempatan untuk mengajukan keberatan atau pendapatnya sebelum suatu keputusan pemerintah mendapatkan bentuk yang definitif. Perlindungan hukum Represif, yaitu bentuk perlindungan hukum dimana ditujukan lebih pada penyelesaian sengketa.

Secara konseptual, perlindungan hukum yang diberikan bagi rakyat Indonesia, merupakan implementasi atas prinsip pengakuandan perlindungan terhadap harkat dan martabat manusia yang bersumber pada Pancasila dan prinsip Negara hukum yang bersumber pada pancasila.

Pembangunan ketenagakerjaan mempunyai banyak dimensi yang tidak hanya berhubungan dengan kepentingan tenaga kerja yang akan, sedang dan telah melakukan hubungan kerja, tetapi 


\section{Aspek yuridis program e-karir dalam perspektif hukum ketenagakerjaan}

Dhaniar Eka Budiastanti, I Gusti Ngurah Adnyana, Adhinda Dewi Agustine

bagaimana caranya agar semua orang mendapatkan pekerjaan dan kelayakan kehidupan bagi kemanusiaan, seperti diamanatkan Pasal 27 ayat (2) dan Pasal 28 D ayat (2) Undang-Undang Dasar 1945. (Charda, 2010)

Hakekatnya setiap orang berhak untuk mendapatkan perlindungan dari hukum. Hampir seluruh hubungan hukum harus mendapatkan perlindungan dari hukum. Terkait dengan perlindungan hukum terkait dengan program e-karir yang ditujukan kepada para pencari kerja agar mudah mengkakses lowongan pekerjaan yang disdiakan baik oleh pemerintah maupun instansi, secara umum telah diatur oleh UU Ketenagakerjaan melalui Pasal 7 dan 8.

Berdasarkan Pasal 7 dan 8 tersebut diatas, maka apabila dikaitkan dengan konstitusi Negara, yaitu Undang-Undang Dasar Negara Republik Indonesia Tahun 1945 (UUD NRI 1945), Pasal 27 ayat (2) UUD NRI 1945, menetapkan bahwa "setiap warga negara berhak atas pekerjaan dan penghidupan yang layak bagi kemanusiaan". Berdasarkan isi pasal 27 ayat (2) UUD NRI 1945 tersebut, maka dapat disimpulkan bahwa dalam hal ini negara menjamin setiap warga negara Indonesia untuk dapat memperoleh pekerjaan yang layak guna mencukupi kehidupan sehari-hari dengan tanpa syarat (Pulungan, Muhamad Sholeh, 2018). Dengan demikian dalam mengatasi persoalan pengangguran, pemerintah harus memberikan solusi dan upaya dalam mengatasi masalah pengangguran dengan kebijakan dan regulasi yang dapat diterapkan dengan baik dan efektif.

Ketentuan Pasal 27 ayat (2) UUD NRI 1945 tersebut diatas, dijabarkan lebih lanjut dalam Pasal 4 Undang-Undang Republik Indonesia Nomor 13 Tahun 2003 tentang Ketenagakerjaan (selanjutnya disebut dengan UU Ketenagakerjaan). Pasal 4 UU Ketenagakerjaan menjelaskan bahwa pembangunan ketenagakerjaan bertujuan untuk: "(1). Memberdayakan dan mendayagunakan tenaga kerja secara optimal dan manusiawi; (2). Mewujudkan pemerataan kesempatan kerja dan penyediaan tenaga kerja yang sesuai dengan kebutuhan pembangunan nasional dan daerah; (3). Memberkan perlindungan kepada tenaga kerja dalam mewujudkan kesejahteraan; dan (4). Meningkatkan kesejahteraan tenaga kerja dan keluarganya". Untuk dapat melaksanakan tujuan di bidang ketenagakerjaan, maka berdasarkan Pasal 7 UU Ketenagakerjaan, ditetapkan perencanaan tenaga kerja dan informasi ketenagakerjaan, yang meliputi: “(1). Penetapan kebijakan pemerintah dan penyusunan perencanaan tenaga kerja; (2). Perencanaan tenaga kerja makro dan mikro; (3). Penyusunan kebijakan, strategi, dan pelaksanaan program pembangunan ketenagakerjaanyang berkesinambungan, pemerintah harus berpedoman pada kebijakan yang telah dibuatnya".

Lebih lanjut, Pasal 8 ayat (1) UU Ketenagakerjaan menentukan bahwa perencanaan tenaga kerja disusun atas dasar informasi ketenagakerjaan, yang diantaranya meliputi informasi kesempatan kerja dan Pasal 8 ayat (2) menyebutkan bahwa: “ imformasi ketenagakerjaan tersebut diperoleh dari semua pihak baik pemerintah maupun swasta". Tata cara yang terkait dengan cata untuk memperoleh informasi ketenagakerjaan tersebut diatur dengan Peraturan Pemeritah, demikian diatur oleh Pasal 8 ayat (3) UU Ketenagakerjaan. Berdasarkan penjabaran tersebut diatas, maka Undang-undang Nomor 13 Tahun 2003 Tentang Ketenagakerjaan telah memberikan Perlindungan hukum terhadap program e-karir guna menekan angka pengangguran di Indonesia. Hal ini berdasarkan Pasal 7 dan 8 UU Ketenagakerjaan.

\section{Kesimpulan}

1. Aspek yuridis program e-karir dalam rangka menekan angka pengangguran telah diatur dalam Undang-undang Nomor 13 Tahun 2003 Tentang Ketenagakerjaan sebagau salah satu kebijakan strategis berskala nasional 


\section{Jurnal Cakrawala Hukum, Volume 11 No. 2 Agustus 2020}

ISSN PRINT 2356-4962 ISSN ONLINE 2598-6538

2. Undang-undang Nomor 13 Tahun 2003 Tentang Ketenagakerjaan telah memberikan perlindungan hukum bagi Pencari Kerja atas ketersediaan lowongan pekerjaan di suatu instansi, melalui Pasal 7 dan 8 yang mengatur mengenai perencanaan dan informasi ketenagakerjaan.

\section{DAFTAR PUSTAKA}

Adnyana, I. 2017. Penjatuhan sanksi dalam penyelesaian perselisihan hubungan industrial. Jurnal Cakrawala Hukum, 19(1), 29-38. doi:10.26905/ idjch.v19i1.1128.

Astuti, P. (1). Analisis kurva phillips dan hukum okun di indonesia tahun 1986-2016. Fokus Bisnis : Media Pengkajian Manajemen dan Akuntansi, 15(1). https:/ /doi.org/10.32639/fokusbisnis.v15i1.72.

Azhar, Muhamad. 2015. Bahan Ajar Hukum Ketenagakerjaan. Semarang. Taruna Akademi Kepolisian.

BPS Indonesia. 2019. Tingkat Pengangguran Terbuka (TPT). https://www.bps.go.id/pressrelease/ 2019/11/05/1565/agustus-2019-tingkatpengangguran-terbuka-tpt-sebesar-5-28persen.html. diakses pada tanggal: 14 Agustus 2019.

Charda, U. 2010. Perlindungan hukum ketenagakerjaan terhadap tenaga kerja anak yang bekerja di luar hubungan kerja pada bentuk pekerjaan terburuk. Syiar Hukum : Jurnal Ilmu Hukum. Vol 12, No 2.

Hakim, MH. 2016. Pergeseran orientasi penelitian hukum: dari doktrinal ke sosio-legal syariah. Jurnal Hukum dan Pemikiran. Volume 16. Nomor 2, Desember 2016. hlm. 105-114.

Ibrahim, Jhony. 2005. Teori dan Metodologi Penelitian Hukum Normatif. Malang. Bayumedia.

Indrawati, I., \& Simanjuntak, T. 2019. Pertanggungjawaban Pidana Terhadap Perusahaan yang Lalai Mendaftarkan Pekerjanya Sebagai Peserta BPJS Ketenagakerjaan. Jurnal Cakrawala Hukum, 10(1), 50-57. doi:10.26905/idjch.v10i1.3180.
Kahfi, Ashabul. 2016. Perlindungan hukum terhadap tenaga kerja. Jurisprudentie : Jurusan Ilmu Hukum Fakultas Syariah dan Hukum. Vol 3, No 2. DOI: https://doi.org/10.24252/jurisprudentie. v3i2.2665.

Lestari, P. (2020). Pengadaan Tanah untuk Pembangunan demi Kepentingan Umum di Indonesia Berdasarkan Pancasila. SIGn Jurnal Hukum, 1(2), 71-86. https://doi.org/10.37276/sjh.v1i2.54.

Lestariyono, D., Sugiri, B., \& Safa'at, R. 2019. Penegakan Hukum Pidana Perusahaan yang Tidak Memenuhi Kewajibannya dalam Program Badan Penyelenggara Jaminan Sosial. Jurnal Cakrawala Hukum, 10(2), 156-165. doi:10.26905/idjch. v10i2.3225.

Otto, Jan Michael. 2003. Kepastian Hukum di Negara Berkembang, Terjemahan Tristam Moeliono. Jakarta. Komisi Hukum Nasional.

Peraturan Presiden Republik Indonesia Nomor 4 Tahun 1980 tentang Wajib Lapor Lowongan Pekerjaan.

Peter Mahmud Marzuki. 2011. Penelitian Hukum. Kencana Prenada Media Group. Jakarta.

Pulungan, MS. 2018. Kajian Yuridis Karakteristik Pengangguran Dalam Perspektif Penyelenggaraan Tenaga Kerja di Provinsi Kalimantan Timur. Jurnal Balitbangda. Vol. 12 No. 1. Hlm. 4-17.

Tim Penulis Status Hukum, 2013, Perlindungan Hukum, http://status hukum.com/perlindunganhukum.html.

Undang-Undang Dasar Negara Republik Indonesia Tahun 1945.

Undang-Undang Negara Republik Indonesia Nomor 13 Tahun 2003 tentang Ketenagakerjaan.

Zora Febriea Dwithia H.P. 2014. Makna Fasilitas Umum "Dalam Pengadaan Tanah Untuk Kepentingan Umum Dalam Mewujudkan Kepastian Hukum Bagi Masyarakat. Tesis. Malang. Universitas Brawijaya. 